\title{
Research of Media Coverage and Its Legal Restrictions on Activities of Criminal Investigation
}

\author{
Jing Yang ${ }^{1, a}$ \\ ${ }^{1}$ Shaanxi Police College, Xi'an, Shaanxi, China, 710021 \\ a email
}

Keywords: Media Coverage, Legal Restriction, Criminal Investigation

\begin{abstract}
With the all-pervasive media involved in social, political, economic and cultural life, the media coverage of judicial activities and legal issues also caused concern. Media reports and judicial power, tension and conflict between the right to a fair trial, the right to highlight the growing personality of legal regulation of media coverage have urgency. This paper attempts within the theoretical framework of rights and powers (right to free speech and judicial power), Rights and Right (media rights and fair trial rights, personality rights) conflict and balanced discussion of the media coverage of judicial activities restricted by law legal basis, principles and standards as well as specific restrictions restrictions and US media reports summarize the judicial activity of legal restrictions inspiration and experience.
\end{abstract}

\section{Introduction}

The concept of freedom of the press, with the development of modern journalism produced is based on an extension of the concept of freedom of speech on the basis of. Modern society everyone lives under the influence of television, newspapers, the Internet and other media, awareness of the rights of the media are increasingly waking up. At the same time, governments are also aware of the importance of the media to protect the right to freedom. In the United States in the struggle for independence and freedom, Jefferson importance of press freedom to express his views, which declared: "If for me to decide whether we should a government without newspapers, or newspapers without a government, I would not hesitate to choose the latter. 1 due to limitations of science and technology, the United States freedom of the press rights awareness awakening that time also reflected only in the traditional media -" newspaper "in. However, with recent advances in modern technology, the scope of freedom of the press coverage has expanded. As digital information continues to develop and progress, many "from the media" as "micro-blogging," "blog" and other new media began to be widely known to the public and widely used. Traditional media have opened the public number, the contents of the paper version of the conversion into an electronic version. Government, courts, prosecutors and other state organs have also established Internet platform, to strengthen ties with the people. As our courts use micro-blogging for pending cases in real time publicly, the government on the Internet to question people's answers. The scope of freedom of the press concept is with social progress constantly changing.

Protection of freedom of the press rights derived based on freedom of expression guaranteed by the state constitution can be said to be an important part of the construction of the rule of law. Citizens understand all aspects of the national information society, in order to enhance communication with national governments and other bodies. Learn the same time to participate in the management of society, through the media to their feedback, which is in need of social progress and development of the rule of law. State media as a communication with the public is an important bridge to the importance of their right to freedom of self-evident. It can be said, precisely because of this kind of news media based on the right to freedom in all aspects of social things that were reported, the rule of law in the country was able to continuously improve. At the national separation of powers, judicial power as one of the three powers of the legislative, executive side by side, which not only has a unique significance as the judiciary, while also taking into account the judicial oversight and legislative guarantees, the exercise of executive power duties. When the legislative 
and executive powers have been violated and when the judicial violations are to impose discipline. When the legislative and executive powers are acrossing its borders, the justice of their actions by "review" 1 to regulate this behavior. Justice has a natural for "fair" choice. But the media published reports of criminal justice, public pressure will sometimes tendentious. These pressure of public opinion, so that a certain degree of judicial activity affected, justice will be compromised in the process. So many times, based on freedom and justice conflict, many judicial workers want their limit, so as not to affect the course of justice.

\section{Criminal Justice Reported Situation and Problem Analysis}

Reported criminal justice and judicial activities, are adhering to the spirit of protection of civil rights, the rule of law to promote national progress. Thus, the reported criminal justice and criminal justice has certainly fit side. In social theory of public relations among the state organs involved in criminal justice activities, we must communicate social organization and community people, which is one of the connotation of the rule of law. State organs adhere to the principle of disclosure of information, protection of sources of information gathering media. The media coverage, but also to protect the citizen's right to know, embodies the true meaning of criminal justice activities. Media and Justice at this level to produce a benign interaction, the construction of a democratic rule of law in our country has a positive effect.

Criminal justice activities are in pursuit of justice, the ultimate safeguard of the public interests of the country. However, due to the special nature of the media profession in criminal justice will be some reports and criminal justice activities to pursue conflicting objectives phenomenon. At this time the media have a negative interaction with the judiciary on the construction of democracy and the rule had a negative impact. We certainly believe that in criminal proceedings, "individual" status is in the prosecuted as weak, so we need to limit the powers of the prosecution and the defense can give the rights of confrontation, and through a series of principles such as "the prosecution shall not conceal evidence in favor of the defense, "and" the defense is entitled to view the dossier, the data "to protect the principles at a certain angle, the Public prosecution is standing defender's position, to protect rights and interests of criminal prosecution of people.

In the media coverage of judicial activities cases, criminal prosecution of persons already in the natural weak position, and closer contact with the audience, such as "Xu Ting Case" in ATM withdrawals this behavior, "Liang Case" in " cartons seized ownerless "these behaviors often occur in real life, when the one-way media coverage in favor of criminal prosecution is caused to resonate with the audience's case details, the prosecution of" guilty accuse "professional people sometimes do not know, a lot of times the media will choose not to report these "to the prosecution." The report was released extremely easy attention and propensity to judge people.

Freedom of the press and right to information is the right basis for criminal justice coverage. Based on this, the media has access to the collection of information and the right to report and comment. Criminal Justice reported that strive for real, comprehensive, and timely. This requires the authoritative media information can be collected in a timely manner. The pursuit of justice and the judiciary, professional. Reported criminal justice information collection, whether it is in the rule of law developed, Western countries a higher legal authority, or the rule of law is not perfect in their countries have in common, as people were voluntarily surrendered the rights to reach a "social contract" and State judiciary formed, which are countries with a strong backing of public power, in the course of criminal proceedings, it is bound to hold the information the defense can not match the ability to collect evidence and the defense can not be obtained. We can say that this ability in the collection of evidence prosecutors possess even the richest defendant can not be reached. 1 while maintaining social stability law as the last line of defense, the judiciary bears the responsibility to protect the people's fight against crime. In this case the judiciary as a maintenance operation of the law of the national public authority, with its natural "authority," which is caused by the nature of the judiciary. So the judiciary on the evidence and details of a case is entitled to judicial "authority." Based on the principle of open justice, the media have the right to obtain details of these cases within reasonable limits. Under this influence, "authoritative", this time the media reports these 
details will be tendentious media unconscious stand on the position of the prosecution, criminal proceedings are to be prosecuted accused person. In these cases, with respect to the judiciary's "authoritative" advice, criminal proceedings have been published and the person prosecuted defender of "defense" it is difficult to gain recognition, as this is due to "individual" to be prosecuted in criminal proceedings and their ability to counsel is limited, compared with the prosecution has a natural weak position, in many cases can not be strong evidence to prove their claims formed. If the prosecution does not give details of the case to regulate the media, then the rights of the defense may suffer great consequences for violations.

\section{Perfection of Criminal Investigation Reported Methods}

In our country, allowing media access to the investigation stage coverage is a necessary requirement of judicial information disclosure, but be sure to grasp the appropriate scale. First, we must adhere to the principle of the suspect's human rights Priority. That is, when the news of freedom and protection of human rights of criminal suspects conflict, priority given to the latter. Especially for juvenile delinquency cases, and cases involving mental patient privacy cases, not open to the community in the investigation process. Of course, under the premise of the establishment of this basic position, can draw lessons from foreign practices, the investigation stage of criminal news reports are divided into National and unnecessary necessary informed informed two, the former is about the political public figures (national staff ), non-political public figures (general public figures) information, which is information about ordinary people. For the crime of ordinary people, citizens do not necessarily need to know, such as non-special circumstances, media reports generally can not sacrifice the reputation and privacy of an ordinary person; but public figures suspected criminal cases, based on theory and officials no privacy and public close links of interest, should be given full media coverage relative to space, the relative weakening of the reputation and privacy of personal protection officers, in order to better take into account the constraints of media abuse, strengthen democracy demands.

Secondly, the investigation reports form to the right. Investigation by the media can be newspapers, magazines, radio, television or other means of program activities and results to the public. In the modern information society, and sometimes must use modern high-tech means and the role of the news media in some cases investigative activities, and timely reporting to the public through the news media, or through the news media, the difficulties encountered in the course of the investigation to the public public, to facilitate the timely detection of cases. While also allow it to report on progress in the investigation of the case, to accept public supervision.

Again, it should take the form of legislation to clarify the scope of investigation reports. To establish open only help control crime and protect human rights when the object is applicable when a case of litigation activities may endanger public safety or harm the interests of the basic human rights of citizens, or possibly a serious departure from the economic efficiency and litigation proceedings to a fair trial when, it should not open. To determine the legal scope for different information to different people disclosed, such as for secret wiretapping and audio and video recording, undercover investigations and other information provided by law must suspects and their defense lawyer kept confidential, but the evidence involving state secrets, should suspect secrecy, but publicly to their defense counsel; but physical examination of the suspect and other information related to personal privacy, it can contribute to the suspects and their defense lawyers disclosed, it should be confidential to the public. In the course of the investigation, if the main evidence of the case has been identified and, if necessary, the prosecution or the Prosecutor may also allow reporters publicly reported cases of the situation.

Finally, to give the necessary legal sanctions for improper investigation activities in media reports. When the media report violations to the suspect's temporary personality, the law should give it some relief ways, such as to sue for compensation of infringement. You can also learn from foreign experience, for a reported violation of the presumption of innocence, the Court gives the suspect application / media gag order, the suspect may be given reasonable to use the media, asking the media to give the forum for clarification. 


\section{Conclusion}

Investigation of information disclosure is a touchstone of the judicial civilization, while safeguarding human rights crimes suspects is an important value of a country, in the realization of the value of the two will conflict, and therefore from legislation and judicial practice, technology continues to improve the balance of conflict, the maximum limit play to guarantee media freedom and human rights investigators suspect activities.

\section{References}

[1] A. Meiklejohn, The First Amendment Is an Absolute, 1961 Sup. Ct. Rev.

[2] Note Hentoff. Speech Harm and Self-government: Understanding the Ambit of the Clear and Present Danger Test, 91 C.L.R.1459-1461(1991).

[3] Henry Commangered. Documents of American History, New York ,1962, 2.

[4] Robert Bork, Neutral Principles and Some First AmendmentProblems,47I.L.J.,(1971).

[5] Vincent Blasi, Toward a Theory of Prior Restraint: The Central Linkage, Minnesota Law Review, 1981, 66.

[6] Howard Hunter, Toward a Better Understanding of the Restraint Doctrine: A Reply to Professor Mayton, Cornell Law Review,1982, 67. 